\title{
The Efforts of Islamic Religious Education Teachers in Fostering Student Morals
}

\author{
Muhammad Muslih \\ Akademi Maritim Cirebon, Indonesia \\ muslihmunaya@gmail.com
}

\begin{abstract}
This research is based on the number of students whose morals are not good because of the free association from the family environment as well as the lack of support in guiding; therefore the role of Islamic religious teachers is needed in these conditions. In several places or the media, we often see how the morals of children are not polite in their interactions, both in terms of actions and words. Islamic religious teachers should play an active role in building student morals, especially in schools. This phenomenon needs handling, especially for Islamic religious education teachers, even though it is only a few hours at school to guide at least there are efforts to improve student morality. This study aims to determine the role of teachers in mentally coaching students, and to know closely how Islamic religious teachers are trying to build the morals of junior high school students. The method used in this study uses field research methods (Field Research) to collect research data using, observation techniques, interviews, document study. After the data is collected, the researcher processes it with qualitative descriptive analysis. This research effort shows that Islamic religious teachers have done their best in guiding students' morality, the efforts made by Islamic religious teachers are to collaborate with related parties, the results of efforts to build morals at SMP Nuba are good seen from the way they act, dress, and speak. the Islamic one.
\end{abstract}

Keywords: Islamic Religion Teachers, Student Morals

Abstak: Penelitian ini didasari atas banyaknya siswa yang akhlaknya kurang baik dikarenakan pergaulan yang bebas selain itu dari lingkungan keluarga juga kurang adanya dukungan dalam membimbing maka dari itu peran guru agama islam sangat dibutuhkan dalam kondisi seperti ini. Dibeberapa tempat atau media sering kita melihat bagaimana akhlak anak-anak kurang sopan dalam pergaulan baik dari tindakan maupun perkataan. Sudah seharusnya guru agama Islam berperan aktif dalam membina akhlak siswa terutama dalam sekolah. Fenomena tersebut perlu adanya penanganan khususnya bagi guru pendidikan agama Islam walaupun di sekolah hanya beberapa jam untuk membimbing setidaknya ada upaya untuk memperbaiki akhlaq siswa. Penelitian ini menggunakan jenis pendekatan penelitian kualitatif. Data dikumpulkan melalui metode wawancara, observasi, dan dokumentasi. Data yang diperoleh di lapangan kemudian disusun dengan memilih dan menyederhanakan data. Selanjutnya dilakukan penyajian data untuk dapat ditarik kesimpulan. Upaya penelitian ini menunjukan hasil bahwa guru agama Islam telah melakukan maksimal dalam membimbing akhlaq siswa, upaya yang dilakukan guru agama Islam adalah melakukan kerjasama dengan yang pihak-pihak yang terkait, hasilnya upaya pembinaan akhlak di SMP Nuha baik terlihat dari cara bertindak, berpakaian, serta berbicarannya yang Islami

Kata Kunci: Guru Agama Islam, Akblak Siswa 


\section{PENDAHULUAN}

Seiring dengan semakin meningkatnya tingkat kekawatiran dan keprihatinan masarakat terutama para orang tua siswa yang disebabkan oleh semakin meningkatnya dekadensi moral dan semakin menguatnya gejala penghancuran nilai-nilai moral, seperti semakin merebaknya obat-obatan terlarang dikalangan generasi muda termasuk didalamnya anak-anak sekolah, semakin bebasnya peredaran pornografi, pergaulan bebas dan lain-lainya, maka lembaga pendidikan baik formal maupun non formal semakin menjadi tumpuhan harapan masyarakat terutama para orang tua siswa dalam membina akhlak siswa dalam keadaan seperti ini maka seorang guru agama Islam semakin dituntut untuk dapat melakukan bimbingan dengan baik serta selalu berorientasi pada pembinaan akhlak siswa.

Proses kegiatan pendidikan khususnya pendidikan Islam harus diarahkan pada upaya pembentukan individu-individu muslim yang berakhlakul karimah. Musthofa Al Gholayan dalam kitabnya Iddhotn Nashibin mengatakan "Pendidikan Islam adalah mananamkan akhlak mulia di dalam jiwa anak dalam masa pertumbuhan dan menyiraminya dengan air petunjuk dan nasihat, sehingga akhlak itu menjadi satu kemampuan meresap dalam jiwanya, kemudian buahnya terwujud keutamaan, kebaikan dan cinta bekerja untuk memanfaatkan cinta tanah air. Pendidikan secara etimologi berasa dari bahasa Yunani yang terdiridari kata "Pais" artinya seseorang, dan "again" diterjemahkan membimbing. ${ }^{1}$

Pada institusi pendidikan islam sesuai dengan dasar sifat dan tujuan pendidikannya, amak seluruh aktivitas bimbingan dan penyuluhan harus dilaksanakan sesuai dengan nilai-nilai Islam dan ajaran Islam. Laksana obat maka bahan-bahan yang diramu untuk mengobati anak-anak didik yang bermasalah harus digali dengan kandungan agama Islam, dengan kata lain bimbingan harus dilakukan atau diberikan berorientasi pada bimbingan keagamaan.

State of the art penelitian ini diambil dari beberapa contoh penelitian terdahulu sebagai panduan ataupun contoh untuk penelitian yang dilakukan saat ini. Salah satu jurnal tersebut berjudul "Upaya Guru Pendidikan Agama Islam Dalam Membina Akhlak Siswa (Studi Kasus di SMP Negeri 1 Bandungan Kab. Semarang)" Aan Afriyawan pada tahun 2016 yang menjelaskan Upaya Guru Pendidikan Agama Islam Dalam Membina Akhlak Siswa (Studi Kasus di SMP Negeri 1 Bandungan Kab. Semarang). Penelitian yang dilakukan sebelumnya hanya sekedar meneliti tentang tutur kata dan prilaku yang di lakukan oleh siswa. Pada kesempatan ini peneliti akan mencoba menggali lebih dalam dari penelitian

13.

${ }^{1}$ Abu Ahmadi dan Nur Uhbiyati, "Ilmu Pendidikan” (Jakarta: Rieneka Cipta, 1991), hal. 
sebelumnya di antaranya akan menggali mengenai berpakaian karena selama ini kebanyak siswa mengindahkan aturan berpakaian yang sudah diterapkan.

Tujuan yang ingin dicapai dalam penelitian ini adalah untuk mengetahui Bentuk-bentuk upaya pembinaan akhlak siswa di SMP Nuha Banjarharjo Brebes, Permasalahan apa saja yang dihadapi guru dalam upaya pemembinaan akhlak siswa di SMP Nuha Banjarharjo Brebes.

Metode adalah suatu pendekatan umum untuk mengkaji topic penelitian. ${ }^{2}$ Penelitian ini menggunakan jenis pendekatan penelitian kualitatif. Data dikumpulkan melalui metode wawancara, observasi, dan dokumentasi. Data yang diperoleh di lapangan kemudian disusun dengan memilih dan menyederhanakan data. Selanjutnya dilakukan penyajian data untuk dapat ditarik kesimpulan.

\section{PEMBAHASAN}

Upaya guru pendidikan agama Islam dalam pembinaan akhlak siswa SMP Nuha Banjarharjo Brebes sejauh ini keberhasilan upaya yang telah dilakukan guru Agama Islam disebabkan beberapa faktor antara lain peran orang tua tentang pentingya kerjasama untuk pembinaan akhlak siswa lingkungan pesantren juga menunjang keberhasilam akhlak siswa, serta pelaksanaan melalui ceramah agama yang sangat tepat mempengaruhi keberhasilan akhlak siswa yang islami

\section{Pengertian Pendidikan Agama Islam}

Pendidikan merupkaan faktor penting bagi kehidupan manusia untuk tumbuh kembangnya. Pendidikan adalah segala pengalaman belajar yang berlangsung dalam segala lingkungan dan sepanjang hidup. Pendidikan adalah segala situasi hidup yang mempengaruhi pertumbuhan individu. ${ }^{3}$ Selain itu peran pendidikan agama juga sangat penting karena agama mengajarkan norma-norma dalam kehidupan.

Dan di dalam Islam, sekurang-kurangnya terdapat tiga istilah yang digunakan untuk menandai konsep pendidikan, yaitu tarbiyah, ta lim, dan ta 'dib. Namun istilah yang sekarang berkembang di dunia Arab adalah tarbiyah. ${ }^{4}$ 2010), 145 .

2Deddy Mulyana, "Metodologi Penelitian Kualitatif' (Bandung: Remaja Rosdakarya, hal.3.

${ }^{3}$ Redja. Muyaharjo, "Pengantar Pendidikan" (Jakarta: Raja Grafindo Persada, 2010), ${ }^{4}$ Hery Nur Aly, “Ilmu Pendidikan Islam” (Jakarta: Logos, 1999), hal. 3. 
Guru dalam Islam adalah orang yang bertanggung jawab terhadap perkembangan anak didik dengan mengupayakan seluruh potensinya, baik potensi afektif, potensi kognitif, maupun potensi psikomotorik ${ }^{5}$. Dengan begitu pengertian guru agama Islam, adalah seorang pendidik yang mengajarkan ajaran Islam dan membimbing anak didik ke arah pencapaian kedewasaan serta membentuk kepribadian muslim yang berakhlak, sehingga terjadi keseimbangan kebahagiaan di dunia dan akhirat.

Pengertian pendidikan secara harfiah berarti membimbing, memperbaiki, menguasai, memimpin, menjaga, dan memelihara. Esensi dari pendidikan adalah adanya proses transfer nilai, pengetahuan, dan keterampilan dari generasi tua kepada generasi muda agar generasi muda mampu hidup. Oleh karena itu, ketika kita menyebut pendidikan agama Islam, maka akan mencakup dua hal, yaitu: a)Mendidik peserta didik untuk berperilaku sesuai dengan nilai-nilai atau akhlak Islam, b)Mendidik peserta didik untuk mempelajari materi ajaran agama Islam. ${ }^{6}$

Sedangkan pengertian pendidikan jika ditinjau secara definitive telah diartikan atau dikemukakan oleh para ahli dalam rumusan yang beranekaragam, diantaranya adalah:

1. Pendidikan Agama Islam sebagai usaha sadar generasi tua untuk mengalihkan pengalaman, pengetahuan, kecakapan, dan keterampilan kepada generasi muda agar menjadi manusia bertakwa kepadaAllah. ${ }^{7}$

2. Pendidikan Agama Islam adalah usaha sadar untuk membimbing kearah pembentukan kepribadian peserta didik secara sistematis dan pragmatis, supaya hidup sesuai dengan ajaran Islam, sehingga terjadinya kebahagiaan dunia akhirat. ${ }^{8}$

3. Muhaimin yang mengutip GBPP PAI, bahwa Pendidikan Agama Islam adalah usaha sadar untuk menyiapkan siswa dalam menyakini, memahami, menghayati, mengamalkan ajaran Islam melalui kegiatan, bimbingan, pengajaran dan latihan dengan memperhatikan tuntutan untuk 2010), 128 .

${ }^{5}$ Muhamad Nurdin, "Kiat Menjadi Guru Profesional” (Jakarta: AR. Ruzz Media Group,

'Dkk Muhaimin, "Paradigma Pendidikan Islam, Upaya Mengefektifkan Pendidikan Agama Islam Di Sekolah” (Bandung: PT Remaja Rosdakarya, 2001), hal. 75-76.

${ }^{7}$ Abdul Majid dan Dian Andayani, "Pendidikan Agama Islam Berbasis Kompetensi,Remaja” (Bandung: Rosdakarya, 2004), hal. 130.

8Zuhairini, "Metodologi Pembelajaran Pendidikan Agama Islam" (Malang: UIN Press, 2004), hal, 11. 
menghormati agama lain dalam hubungan kerukunan antar umat beragama dalam masyarakat untuk mewujudkan persatuan nasional. ${ }^{9}$

\section{Tujuan Pendidikan Islam}

Tujuan ialah suatu yang diharapkan tercapai setelah sesuatu usaha atau kegiatan selesai. Jika kita melihat kembali pengertian pendidikan agama Islam, akan terlihat dengan jelas sesuatu yang diharapkan terwujud setelah orang mengalami pendidikan Islam secara keseluruhan, yaitu kepribadian seseorang yang membuatnya menjadi "insan kamil" dengan pola taqwa insan kamil artinya manusia utuh rohani dan dapat hidup dan berkembang secara wajar dan normal karena takwanya kepada Allah SWT. Dalam hal ini ada beberapa tujuan Pendidikan Agama Islam yaitu:

\section{Tujuan Umum (Institusional)}

Tujuan umum ialah tujuan yang akan dicapai dengan semua kegiatan pendidikan, baik dengan pengajaran atau dengan cara lain. Tujuan itu meliputi seluruh aspek kemanusiaan yang meliputi sikap, tingkah laku, penampilan, kebiasaan, dan pandangan. Bantuk insan kamil dengan pola takwa harus dapat tergambar pada pribadi seseorang yang sudah dididik, walaupun dalam ukuran kecil dan mutu yang rendah, esuai dengan tingkat-tingkat tersebut. Tujuan umum pendidikan harus dikaitkan pula dengan tujuan pendidikan nasional Negara tempat pendidikan.

\section{Tujuan Akhir}

Pendidikan Islam itu berlangsung selama hidup, maka tujuan akhirnya tedapat pada waktu hidup di dunia ini telah berakhir pula. Tujuan umum yang berbentuk Insan Kamil dengan pola takwa dapat mengalami naik turun, bertambah dan berkurang dalam perjalanan hidup seseorang.

Karena itulah pendidikan Islam itu berlaku selama hidup untuk menumbuhkan, memupuk, mengembangkan, memelihara, dan mempertahankan tujuan pendidikan yang telah dicapai. Tujuan akhir Pendidikan Agama Islam akan dapat lebih dipahami dalam firman Allah SWT yang Artinya: "Hai orangorang yang beriman, bertakwalabkepada Allah sebenarbenartakwakepadaNya, danjanganlahsekali-kali kamumatimelainkandalamkeadaanberagama Islam." (QS. AlImran: 102) ${ }^{10}$

${ }^{9} \mathrm{dkk}$ Muhaimin, "Paradigma Pendidikan Islam, Upaya Mengefektifkan Pendidikan Agama Islam Di Sekolah” (Bandung: PT. Rosdakarya, 2001).

${ }^{10}$ Depag RI, “Al- Qur'an Dan Terjemahnya” (Semarang: Toha Putra, 1989). 


\section{Tujuan Sementara (Instruksional)}

Tujuan sementara adalah tujuan yang akan dicapai setelah seseorang didik diberi sejumlah pengalaman tertentu yang direncanakan dalam suatu kurikulum pendidikan formal. Pada tujuan sementara bentuk insane kamil dengan pola waktu sudah kelihatan meskipun dalam ukuran sementara, sekurang-kurangnya beberapa cirri pokok sudah kelihatan pada pribadi seseorang didik.

\section{Tujuan Operasinal}

Tujuan Operasional adalah tujuan praktis yang akan dicapai dengan sejumlah kegiatan tertentu. Satu unit kegiatan pendidikan dengan bahan-bahan yang sudah dipersiapkan dan diperkirakan akan mencapai tujuan tertentu disebut tujuan operasional. Dalam tujuan operasional ini lebih banyak dituntut dari seseorang didik suatu kemampuan dan keterampilan tertentu. Sifat operasionalnya lebih ditonjolkan dari sifat penghayatan dan kepribadian. Untuk tingkat yang paling rendah, sifat yang berisi kemampuan dan keterampilanlah yang ditonjolkan. Misalnya, ia dapat berbuat, terampil melakukan, lancer mengucapkan, mengerti, memahami, menyakini dan menghayati adalah soal kecil. Dalam pendidikan hal ini terutama berkaitan dengan kegiatan lahiriyah, seperti bacaan dari kafiyat shalat, akhlak, dan tingkah laku. ${ }^{11}$

\section{Pengertian Akhlak}

Akhlak dalam bahasa Indonesia berasal dari bahasa arab "akhlaq" bentuk jamak kata "khuluq" atau "al-khulq" yang berarti budi pekerti, perangai, tingkah laku, atau tabi'at. ${ }^{12}$

Secara etimologis, kata akhlak adalah sebuah kata yang berasal dari bahasa arab "al-akhlaq". Ia merupakan bentuk jama' dari kata alkhuluq yang berarti budi pekerti, tabiat atau watak. Dengan demikian, maka kata akhlak merupakan sebuah kata yang digunakan untuk mengistilahkan perbuatan manusia yang kemudian diukur dengan baik atau buruk. Dan dalam Islam, ukuran yang digunakan untuk menilai baik atau buruk itu tidak lain adalah ajaran Islam sendiri ${ }^{13}$.

Akhlak adalah sifat yang tertanam dalam jiwa yang menimbulkan perbuatan perbuatan dengan gampang dan mudah, tanpa memerlukan pemikiran

\footnotetext{
${ }^{13}$ Nipan Abdul Halim, "Menghias Diri Dengan Akhlak Terpuji" (Yogyakarta: Pustaka Pelajar, 2000), hal. 7-8.
} 2008), hal. 346.

${ }^{11}$ Zakiyah Darajat, "Ilmu Pendidikan Islam” (Jakarta: Bumi Aksara, 1992), 30.

${ }^{12}$ Mohammad Daud, "Pendidikan Agama Islam" Jakarta: Raja Grafindo Persada, 
dan pertimbangan. ${ }^{14}$ Kata kbuluqiyah atau Akblak larim disebut dengan moral. Yaitu sebuah sistem yang lengkap yang terdiri dari karakteristik-karakteristik akal atau tingkah laku yang membuat seseorang menjadi istimewa ${ }^{15}$. Karakteristikkarakteristik ini membentuk kerangka psikologi seseorang dan membuatnya berperilaku sesuai dengan dirinya dan nilai yang cocok dengan dirinya dalam kondisi yang berbeda-beda.

\section{Jenis-jenisAkhlak}

Akhlak sebagaimana dikemukakan di atas adalah kehendak jiwa yang mendorong seorang tanpa dipikir panjang dan tanpa pertimbanganpertimbangan tertentu untuk melakukan sesuatu. Dalam wacana keilmuawan (ilmu akhlak) akhlak dikelasifikasikan menjadi dua, yakni akhlakul karimah dan akhlakul madmumah

\section{Akhlakul Karimah}

Akhlakul karimah adalah akhlak (perbuatan) baik kepada Allah, kepada sesama manusia maupun kepada makhluk lain yang telah diajarkan oleh Islam yang sesuai dengan semangat ajaran Islam sebagai rahmat bagi umat manusia. Secara garis kecil yang termasuk dalam akhlakul karimah antara lain

\section{Shidiq}

Kata shidiq dalam bahasa arab berasal dari kata ash-shidqu yang artinya jujur atau benar. Orang baik atau benar dalam perkataan maupun perbuatan disebut ash-shiddieq. Rasulullah SAW memerintahkan kepada umatnya agar selalu berbuat jujur, karena kejujuran dapat mendatangkan kebaikan dan kebaikan merupakan jalan kesurga. Beliau bersabda yang artinya "Hendaklah kamu skalian bersifat jujur, karena kejujuran akan membawa kebaikan dan kebaikan akan membawa ke surga. Seseorang yang selalu jujur dan mencari kejujuran akan ditulis oleh Allah sebagai seorang yang jujur dan jauhilah berbuat bohong, karena kebohongan akan membawa kejahatan dan kejahatan akan membawa ke neraka. Orang yang selalu berbohong dan mencari kebohongan akan ditulis oleh Allah sebagai pembohong (kadzdzab)".(HR Bukhori)

\section{Amanah}

Amanah arrtinya dapat dipercaya. Dalam arti sempit amanah berarti memelihara titipan dan mengembalikannya dalam keadaan semula. Dalam arti luar amanah meliputi perbuatan menjaga diri sendiri, menunaikan tugas dan tanggung jawab yang diberikan, menyimpan rahasia seseorang, menjaga

${ }^{14}$ Asmaran, "Pengantar Studi Akhlak" (Jakarta: Raja Grafindo Persada, 2002), hal. 3.

${ }^{15}$ Abdul Halim Mahmud, "Akhlak Mulia” (Jakarta: Gema Insani Press, 2004), hal. 2627. 
kehormatan orang dan lain-lain.semakin tebal keiman seseorang maka akan semakin tampak sifat amanah dalam dirinya. Rasulullah bersabda yang artinya "tidak sempurna iman seseorang yang tidak memiliki sifat amanah dan tidak sempurna agama seseorang yang tidak menempati janji”"

\section{Tawadlu}

Tawadlu artinya rendah hati. Orang yang bertawadlu senantiasa bersikap rendah hati. Ia tidak akan pernah memnadang orang lain yang lebih rendah darinya, sekalipun ia sebenarnya berkedudukan lebih tinggi dari yang lain. Orang yang tawadlu senantiasa menghayati, merenungkan dan mengamalkan firman Allah dalam Al-Quran yang artinya "Dan apa saja ni'mat yang ada pada kamu, maka dari Allah lah (datangnya) dan apabila kamu ditimpa kemudlorotan maka hanya kepadanyalah kamu meminta pertolongan".

\section{Sabar}

Sabar secara etimologis berarti menahan dan mengekang. Sedangkan secara terminologi berarti menahan diri dari segala sesuatu yang tidak disukai karena mengharap ridlo Allah SWT. Imam Al-Ghozali sebagaimana dikutip oleh Supiana Dkk mengatakan bahwa sabar adalah kondisi jiwa dalam mengendalikan nafsu yang terjadi karena dorongan agama. Imam Ghozali membagi sabar dalam tiga tingkatan:

1. Sabar tertinggi ya'ni sifat yang mampu menghadapi semua dorongan nafsu sehingga nafsu benar-benar dapat ditundukan

2. Sabar orang-orang yang dalam perjuangan. Pada tahap ini orang kadangkadang dapat menguasi hawa nafsu terkadang mereka dikuasai hawa nafsu, sehingga tercampur antara yang baik dan yang buruk

3. Tingkat terendah yaitu sabar karena kuatnya hawa nafsu dan kalahnya dorongan agama

\section{Akhlakul Madmumah}

Suatu perbuatan dapat dikategorikan sebagai akhlakul madmumah apabila bertentangan dengan nilai-milai ajaran Islam atau semangat yang dibawa oleh ajaran Islam maka perbuatan tersebut masuk dalam kategori akhlak yang tercela (akhlak mahmmudah) dan harus dijauhi dan dihindari. Yang termasuk sifat akhlakul madmumah adalah

\section{Al-Kidzbu}

Al-Kidzbu adalah istilah dalam bahasa arab yang berarti berbohong. Orang yang berbohong disebut kad₹dzab. Al-kid₹bu (bohong) merupakan kebalikan dari pada al-shidqu (jujur) 


\section{Khiyanat}

Khiyanat merupakan kebalikan dari amanah. Khiyanat merupakan salah satu bentuk kebohongan yang sangat nyata dan berbahaya. Khiyanat dalam kehidupan berbangsa dan bernegara merupakan racun yang sangat mematikan dan sumber malapetaka yang sangat besar.

\section{Takabur atau Sombong}

Takabbur dan sombong merupakan kebalikan dari tawadlu atau merendahkan diri. Takabbur adalah sikap menyobongkan diri, merasa diri paling tinggidan paling mulia dari yang lain sehingga selalu merendahkan orang lain.

\section{Upaya guru Agama Islam dalam pembinaan akhlak siswa}

Tertatanya nilai-nilai akhlak yang tercermin pada sikap dan prilaku siswa sehari-hari baik di lingkungan sekolah, lingkungan rumah maupun di luar kedua lingkungan tersebut merupakan salah satu kriteria keberhasilan program, pendidikan dan pengajaran pada sebuah lembaga pendidikan. Di sekolah peran guru Agama Islam dalam membina akhlak siswa dilakukan dengan berbagai upaya. Adapun upaya-upaya yang selama ini dilakukan berdasarkan hasil wawancara dengan guru Agama Islam tersebut adalah sebagai berikut:

\section{Menginventarisir dan perkembangan Akhlak siswa}

Inventarisis data tentang perkembangan akhlak siswa merupakan upaya yang sangat penting untuk dilakukan. Upaya inventarisasi dilakukan sebagai tahap awal dalam pembinaan akhlak ibarat dokter, upaya ini dilakukan untuk mengetahui kondisi pasienyang akan dijadikan dasar tindakan bagi dikter dalam rangka proses penyembuhan. Upaya inventarisasi data tentang perkembangan akhlak siswa oleh guru Agama Islam dilakukan dengan berbagai cara yaitu bekerjasama dengan wali kelas, para guru orang tua murid.

\section{Mengadakan ceramah agama}

Upaya lain oleh guru Agama Islam dalam rangka membina akhlak para siswa yaitu dengan memberikan sentuhan-sentuhan keagamaan melaluui ceramah agama Islam, upaya ini dilakukan dengan mengadakan peringatan hari besar Islam dengan memanggil penceramah, mengadakan sholat berjamaah secara rutin dan bergiliran setiap kelas dan dilanjutkan dengan ceramah agama atau yang biasa disebut dengan kultum yang disampaikan oleh para guru yang dianggap mampu baik secara keilmuan maupun moral

\section{Melakukan pendekatan personal}

Upaya ketiga yang dilakukan oleh guru Agama Islam dalam rangka membina akhlak siswa adalah dengan melakukan pendekatan personal terhadap 
para siswa yang berdasarkan data baik dari wali kelas maupun dari guru yang lain, maupun dari orang tua diketahui atau terindikasi mengalami perkembangan kakhlak negatif, seperti sering melakukan perkelahian, terlihat dalam kasus narkoba atau minuman keras baik sebagai pengguna maupun pengedar, pemalakan, berpenampilan yang sangat tidaksesuai dengan norma-norma, dan perbuatan-perbuatan yang lainnya yang dianggap sebagai kenakalan atau penyimpanan yang dapat menghancurkan akhlak mereka.

\section{KESIMPULAN}

Berdasarkan uraian-uraian tentang upaya pembinaan yang telah dilakukan olehb guru Agama Islam dalam membina akhlak siswa SMP NuhaBanjarharjo Brebes, maka dapat dikemukakan bebrapa kesimpulan sebagai berikut:

Pembinaan akhlak siswa SMP Nuha Banjarharjo Brebes oleh guru Agama Islam sesuai dengan kemampuannya telah dilakukan secara maksimal. Beberapa upaya yang sangat penting yang telah dilakukannya adalah melakukan kerjasama dengan para wali kelas, para guru baik secara formal maupun non formal dan para orang tua siswa guna menginventarisir data-data tentang perkembangan akhlak siswa. Cara kedua dengan menyelenggarakan ceramah agama baik melalui kegiatan peringatan har-hari besar Islam maupun dengan mewajibkan para siswa untuk sholat duhur berjamaah dn dilanjutkan dengan ceramah oleh guru yang telah ditunjuk sebelumnya. Dan cara terakhir yang ditempuh oleh guru Agama Islam dalam membina akhlak siswa SMP Nuha Banjarharjo Brebes, adalah dengan melakukan pendekatan secara personal

Upaya Pembinaan akhlak siswa SMP Nuha Banjarharjo Brebes, berhasil dengan baik. Hal ini dapat dilihat dari cara penampilan, berpakaian, prilaku sehari-hari siswa yang mencerminkan akhlak islami, juga terlihat siswa yang tidak terlibat dalam kenakalan remaja dan lain-lainnya.

Keberhasilan upaya yang telah dilakukan guru Agama Islam disebabkan beberapa faktor antara lain peran orang tua tentang pentingya kerjasama untuk pembinaan akhlak siswa lingkungan pesantren juga menunjang keberhasilam akhlak siswa, serta pelaksanaan melalui ceramah agama yang sangat tepat mempengaruhi keberhasilan akhlak siswa yang islami. 


\section{BIBLIOGRAPHY}

Abdul Majid dan Dian Andayani. "Pendidikan Agama Islam Berbasis Kompetensi,Remaja,".Bandung: Rosdakarya, 2004.

Abu Ahmadi dan Nur Uhbiyati. "Ilmu Pendidikan,". Jakarta: Rieneka Cipta, 1991.

Asmaran. "Pengantar Studi Akhlak,". Jakarta: Raja Grafindo Persada, 2002.

Daud, Mohammad. "Pendidikan Agama Islam,”. Jakarta: Raja Grafindo Persada, 2008.

Depag RI. “Al- Qur'an Dan Terjemahnya.” Semarang: Toha Putra, 1989.

Halim, Nipan Abdul. "Menghias Diri Dengan Akhlak Terpuji," Yogyakarta: Pustaka Pelajar, 2000.

Hery Nur Aly. "Ilmu Pendidikan Islam,". Jakarta: Logos, 1999.

Mahmud, Abdul Halim. "Akhlak Mulia,". Jakarta: Gema Insani Press, 2004.

Muhaimin, dkk. "Paradigma Pendidikan Islam, Upaya Mengefektifkan Pendidikan Agama Islam Di Sekolah.” Bandung: PT. Rosdakarya, 2001.

Muhaimin, Dkk. "Paradigma Pendidikan Islam, Upaya Mengefektifkan

Pendidikan Agama Islam Di Sekolah,”. Bandung: PT Remaja Rosdakarya, 2001.

Mulyana, Deddy. "Metodologi Penelitian Kualitatif,". Bandung: Remaja Rosdakarya, 2010.

Muyaharjo, Redja. "Pengantar Pendidikan,". Jakarta: Raja Grafindo Persada, 2010.

Nurdin, Muhamad. "Kiat Menjadi Guru Profesional,". Jakarta: AR. Ruzz Media Group, 2010.

Zakiyah Darajat. "Ilmu Pendidikan Islam,". Jakarta: Bumi Aksara, 1992.

Zuhairini. "Metodologi Pembelajaran Pendidikan Agama Islam," hal, 11. Malang: UIN Press, 2004. 
38 | Belajea: Jurnal Pendidikan Islam, Vol. 6, No. 1, 2021 